\title{
АКТУАЛЬНІСТЬ СИНДРОМУ ХРОНІЧНОЇ ВТОМИ СЕРЕД МОЛОДІ, ЕТІОЛОГІЯ I ПЕРШІ ПРОЯВИ
}

\author{
Н. В. Богдан, О. I. Зарудна \\ Чемеровецький державний медичний коледж \\ Чемеровецька центральна районна лікарня \\ ДВНЗ «Тернопільський державний медичний університет \\ імені I. Я. Горбачевського МОЗ України"
}

\begin{abstract}
У статті проаналізовано поширеність синдрому хронічної втоми серед молоді, зокрема серед студентів, а також причини та перші симптоми захворювання.
\end{abstract}

\section{TOPICALITY OF CHRONIC FATIGUE SYNDROME AMONG YOUTH, ETIOLOGY AND FIRST SYMPTOMS}

\author{
N. V. Bohdan, O. I. Zarudna \\ Chemerivtsi State Medical College \\ Chemerivtsi Central District Hospital
}

SHEI «Ternopil State Medical University by I. Ya. Horbachevsky of MPH of Ukraine»

The article analyzes the prevalence of chronic fatigue syndrome among youth, students, and causative factors, first symptoms of the disease.

Вступ. Однією з найактуальніших проблем сьогодення є проблема хронічно втоми. Серед усіх вікових категорій, а особливо серед молодих людей, спостерігається тенденція до зростання поширеності даного захворювання. Це пов'язано з особливостями життя сучасно молоді. Стреси, порушення режиму харчування, екологічні фактори, поєднання роботи і навчання - все це у сукупності негативно впливає як на фізіологічний, так і психологічний стан молодо людини.

Основна частина. Враховуючи незначну кількість досліджень і відсутність бажання проводити ретельні епідеміологічні дослідження, не дивно, що дані про поширеність синдрому хронічно втоми широко варіюють. За різними даними поширеність захворювання становить 1037 випадків на 100 тис. населення [7].

Так, наприклад, у США за даними Американсько асоціаці синдрому хронічно втоми та імунних дисфункцій (AACFIDS An. Rep., 2001) захворюваність складає 4,7 \% в популяці дорослого населення США.

(ㄱ.․ В. Богдан, О. І. Зарудна, 2015
Щодо інших кра н світу, то варто зазначити, що найнижча захворюваність зареєстрована в Австралі - 0,04 \%, Італі - 0,2 \%, Нідерландах $7 \%$ (A. vanAvelen, 2000; Conti F., 1994). Досить високий рівень захворюваності на синдром хронічно втоми спостерігається в Японі (3,2\%), при цьому серед підлітків дано кра ни показник становить до $9 \%$ (Tamoda H., 2002).

В Украні за результатами анкетування 500 людей, відібраних методом випадково вибірки, захворюваність склала 6,5\%. Серед підлітків (дані анкетування 400 дітей віком 1016 років) захворюваність становить 5,7 \%. Причому дівчата в періоді раннього пубертату (1214 років) складають 81 \% хворих підлітків (Стеблюк В., 2001) [6].

Звісно, синдром хронічно втоми може розвиватися в будь-якому віці, але найчастіше - у віці 20-40 років. Світові статистичні дані свідчать, що захворювання спостерігається в жінок у 2 рази частіше, ніж у чоловіків. За деякими даними щоденно у світі реєструється до 1000 тис. випадків синдрому хронічно втоми [8].

Клінічні спостереження показали високу частоту захворювання серед студентів і спортс- 
менів з високими досягненнями. Вони амбітні, хочуть досягти своє мети, працюють вдень і вночі, докладають надлюдські зусилля. Вони часто отримують більше, ніж хні колеги. Проте за це доводиться платити високу ціну, і ціна ця - синдром хронічно втоми, який уражає близько 17 млн чоловік у всьому світі. $Є$ випадки смерті від перевтоми [9].

Перевтома і виснаження найпоширеніші ceред молодих людей, освічених, амбітних, успішних і зайнятих досягненням своє мети будьякими шляхами. Кажуть, що життя на високій швидкості має свою ціну - це синдром хронічно втоми, який був визнаний ВООЗ захворюванням.

Синдром хронічно втоми (СХВ) - це захворювання, яке характеризується безпричинним відчуттям втоми і слабкості протягом не менш як 6 місяців, і не минає навіть після тривалого відпочинку.

Необхідно відрізняти синдром хронічно втоми від просто втоми, яка просто $є$ фізіологічним сигналом того, що організм потребує відпочинку $[10,11,12]$.

Причини синдрому хронічно втоми невідомі, проте є ряд різноманітних теорій - від теорі вірусного (вірус Епштейн-Барра, герпесу) і до теорі психологічного стресу. Розбіжність поглядів у вчених зумовлена різноманітністю симптомів та кількістю уражених систем. Адже синдром хронічно втоми - це багатофакторне захворювання $з$ переважним ураженням Функцій ЦНС, імунно та ендокринно систем, у відповідь на різні ендогенні та екзогенні фактори [13].

Фактори ризику синдрому хронічно втоми:

- вік (частіше 30-50 років);

- жіноча стать;

- перенесені захворювання;

- стрес;

- порушення режиму сну;

- гормональні порушення;

- нераціональне харчування, гіпо- і авітаміноз;

- генетичні фактори;

- Фактори навколишнього середовища;

- шкідливі звички [1-6].

Часто саме шкідливі звички стають провокуючим фактором появи захворювання:

- нераціональне і надто калорійне харчування, що може призвести до ожиріння;

- алкоголізм у формі побутового як варіант зняття нервового і стресового напруження;

- інтенсивне куріння як засіб стимулювання працездатності.

На сьогодні не існує точно діагностично системи, окрім критері в CDC, за допомогою яко було б можливо чітко діагностувати синдром хронічно втоми, а тому застосовують комплексний підхід (табл. 1):

- визначення активності автономно нервово системи;

- дослідження гормонального та імунологічного профілю;

- оцінка загального функціонального стану організму;

- опитувальники - тести [14].

Прийняті центром з контролю і профілактики захворювань (Centers for Disease Control and Prevention - CDC) критері CXВ є досить широкими. Сучасні діагностичні критері сформулював Fukuda K. et al. у 1994 році, розміщені на офіційному сайті CDC [15-18]:

- наявність хронічно втоми більше 6 місяців або довше, за умови виключення іншого клінічного діагнозу;

- втома конкурує з щоденною активністю та роботою.

Пацієнт повинен мати одночасно 4 з 8 перерахованих симптомів:

- втома після фізично активності, що триває більше, ніж 24 години;

- відсутність відчуття відпочинку після нічного сну;

- істотне зниження короткочасно пам'яті та уваги;

- м'язовий біль;

- поліартралгі, біль без припухлості та почервоніння;

- поява головного болю з новими характеристиками, ніж раніше;

- болючі шийні та аксілярні лімфатичні вузли;

- рецидивуючий та тривалий біль у горлі.

Інші симптоми, що часто спостерігаються у хворих на СХВ це: відчуття розгубленості, головокружіння, труднощі при утримуванні балансу тіла, алергічні прояви, підвищена чутливість до шуму, симптоми подразненого кишечника, лихоманка, нічна пітливість, підвищена чутливість до світла, біль в очах, депресія, подразливість, швидка зміна настрою, страх, панічні атаки, тривалий біль, порушення сну [19].

СХВ може бути діагностовано після ретельно диференційно діагностики:

- медикаментозно залежності;

- імунних чи автоімунних порушень;

- інфекцій;

- захворювань м'язів чи нервово системи (наприклад, розсіяний склероз);

- ендокринних захворювань (наприклад, гіпотиреоз);

- інших захворювань (серця, нирок, печінки тощо);

- психіатричних захворювань;

- пухлин. 
Таблиця 1. Клініко-лабораторні тести, показані пацієнтам із втомою невідомої етіології (FosnochtK.M. et al., 2008; FukudaK. et al., 1994; LaneT.J. et al., 1990)

\begin{tabular}{|c|c|c|}
\hline Тест & Можливий діагноз & Примітка \\
\hline Розгорнутий загальний аналіз крові & Анемія & \multirow{6}{*}{$\begin{array}{l}\text { Ці тести слід виконувати в } \\
\text { більшості пацієнтів } 3 \text { втомою } \\
\text { тривалістю } 2 \text { тижні; їх } \\
\text { результати можуть змінити } \\
\text { схему лікування в } 5 \text { \% хворих } \\
\text { (Lane T. J. et al., 1990) }\end{array}$} \\
\hline ШOE & Запалення & \\
\hline Біохімічний аналіз крові & $\begin{array}{l}\text { Захворювання печінки, ниркова } \\
\text { недостатність, недостатнє } \\
\text { споживання білків }\end{array}$ & \\
\hline $\begin{array}{l}\text { Тести для оцінки функції } \\
\text { щитоподібоної залози }\end{array}$ & Гіпотиреоз & \\
\hline Антитіла до ВІЛ & Хронічна інфекція & \\
\hline Тест на вагітність (при показаннях) & $\begin{array}{l}\text { Вагітність, задишка зумовлена } \\
\text { прогестинами }\end{array}$ & \\
\hline Оглядова рентгенографія ОГК & Аденопатія, рак & \multirow{10}{*}{$\begin{array}{l}\text { Ці тести рідко ефективні; } \\
\text { призначати тільки тоді, коли } \\
\text { показані за результатами } \\
\text { фізикального обстеження або } \\
\text { аналізів крові }\end{array}$} \\
\hline Реакція Манту & Туберкульоз, хронічна інфекція & \\
\hline EKГ & $\begin{array}{l}\text { Застійна серцева недостатність, } \\
\text { аритмія }\end{array}$ & \\
\hline Тести для оцінки функції легень & $\begin{array}{l}\text { Хронічні обструктивні } \\
\text { захворювання легень, рак }\end{array}$ & \\
\hline Скринінг на токсини & Зловживання певними речовинами & \\
\hline Тести для виключення хвороби Лайма & Хронічна форма хвороби Лайма & \\
\hline Тести для виключення сифілісу & Сифіліс & \\
\hline МРТ головного мозку & Розсіяний склероз & \\
\hline ExoKГ & $\begin{array}{l}\text { Патологія клапанів серця, застійна } \\
\text { серцева недостатність }\end{array}$ & \\
\hline $\begin{array}{l}\text { Спеціалізовані тести крові } \\
\text { (наприклад, рівень феритину, заліза, } \\
\text { вітаміну В }{ }_{12} \text { і фолатів; здатність до } \\
\text { зв'язування заліза; пряма реакція } \\
\text { Кумбса) }\end{array}$ & $\begin{array}{l}\text { Дефіцит заліза, хвороба Аддісона, } \\
\text { целіакія, myasthenia gravis, } \\
\text { отруєння }\end{array}$ & \\
\hline
\end{tabular}

Висновки. Згідно з статистичними даними синдром хронічно втоми, як хвороба цивілізаці, набуває все більших обертів серед різних категорій населення. Водночас, для встановлення такого діагнозу необхідно прикласти чима-

\section{ЛITEPATYPA}

1. Santhouse A. Chronic fatigue syndrome / A. Santhouse, M. Hotopf, A. S. David // BMJ. - 2010. Vol. 340. - P. 738.

2. Fosnocht K. M. Approach to the adult patients with fatique. http: / / www.uptodate.com/home. Accessed Dec. 28,2012

3. Chronic Fatigue Syndrome. Medline Plus website. Available at: http://www.nlm.nih.gov/medlineplus/ ency/article/001244.htm. Accessed January 2011.

4. Chronic Fatigue Syndrome. Center for Disease Control and Prevention website. Available at: http:// www.cdc.gov/cfs/. Accessed January 2011. ло зусиль, виключивши найпоширеніші та очевидні причини втоми іншого походження. Встановлення істини дає змогу скласти план ефективних заходів лікування та реабілітаці пацієнта.

5. Mayo Clinic Staff. CFS, Risk Factors (Online Information). Available online at http:// www.mayoclinic.com / health / chronic-fatiguesyndrome/DS00395/DSection through http:// www.mayoclinic.com. Accessed September 2012.

6. Синдром хронічної втоми на практиці [Електронний ресурс]. - Режим доступу : http://medbib.in.ua/ sindrom-hronicheskoy-ustalosti-praktike.html

7. Профрілактика синдрому хронічної втоми [Електронний ресурс]. - Режим доступу : http:// knowledge.allbest . ru / medicine / 3c0a65635a2bd78b4d53a89421216d37_0.html 
8. Лікування синдрому хронічної втоми [Електронний ресурс]. - Режим доступу : http:// uk. shram.kiev.ua/health/narod/sindrom-hronicheskoiustalosti.shtml

9. Julian M Stewart, MD, PhD, і співавт. http://imedic.com.ua/index. php?newsid=3756

10. Fatigue: An Overview / T. C. Rosenthal, B. A. Majeroni, R. Pretorius, K. Malik / / Am. Fam. Physician. - 2008. - Vol. 78 (10). - P. 1173-1179.

11. Viner R. Fatigue and somatic symptoms / R. Viner, D. Christie / / BMJ. - 2005. - Vol. 330 (7498). - P. 10121015.

12. Fosnocht K. M. Approach to the patient with fatigue / K. M. Fosnocht, J. Ende // http:// www.uptodate.com.

13. Медичні статті «Терапія » Синдром хронічної втоми. - http: / /i-medic.com.ua/index.php?newsid=23672

14. Електричні потенціапи шкіри в осіб з різними показниками тесту "Синдром хронічної втоми" / М. Ю. Макарчук, В. Б. Богданов, Т. В. Куценко [та ін.] / / Вісник ЛНУ імені Тараса Шевченка. - 2010. - № 21 (208). C. 35-42.
15. Larun L. Identity and coping experiences in Chronic Fatigue Syndrome: A synthesis of qualitative studies / L. Larun, K. Malterud / / Patient Education and Counseling. - 2007. - Vol. 69. - P. 20-28.

16. Firestein G. S. Kelley's Textbook of Rheumatology. 8th ed. / G. S. Firestein, R. C. Budd, E. D. Jr. Harris [et al.] // Philadelphia, Pa: Saunders Elsevier. - 2008.

17. Engleberg N. C. Chronic fatigue syndrome. In: G. L. Mandell, J. E. Bennett, R. Dolin, eds. Principles and Practice of Infectious Diseases. 7th ed. Philadelphia, Pa: Elsevier Churchill Livingstone; 2009:chap 131.

18. Santhouse A. Chronic fatigue syndrome/ A. Santhouse, M. Hotopf, A. S. David // BMJ. - 2010. Vol. 340. - P. 738.

19. Mira Meeus. Central sensitization: a biopsychosocial explanation for chronic widespread pain in patients with fibromyalgia and chronic fatigue syndrome / Mira Meeus, Jo Nijs / / Clin Rheumatol. - 2007. - Vol. 26. - P. 465$473 ; 465-473$. 